\title{
New insights of $\mathrm{Nb}_{2} \mathrm{O}_{5}$-based coatings on the $316 \mathrm{~L}$ SS surfaces: enhanced biological responses
}

\author{
Jéferson Aparecido Moreto $\mathbb{D}^{1} \cdot$ Rogério Valentim Gelamo $^{2} \cdot$ Marcos Vinicius da Silva $^{3} \cdot$ Teresa Tromm Steffen $^{4}$. \\ Carlo José Freire de Oliveira ${ }^{3}$ - Patrícia Andressa de Almeida Buranello ${ }^{1} \cdot$ Marcelo Rodrigues Pinto $^{5}$
}

Revised: 1 February 2021 / Accepted: 16 February 2021 / Published online: 6 March 2021

(c) The Author(s) 2021

\section{Abstract}

This communication aims to propose new insights of $\mathrm{Nb}_{2} \mathrm{O}_{5}$-based coatings on the $316 \mathrm{~L}$ SS surface with great prospects to be used in the dentistry field as brackets. The $\mathrm{Nb}_{2} \mathrm{O}_{5}$ thin film was incorporated into the $316 \mathrm{~L}$ SS by using PVD method. For this purpose, the studied system was characterized structurally and morphologically by using AFM, FTIR-IRRAS, Raman spectroscopy and X-ray photoelectron spectroscopy (XPS). Biological assays were performed using human gingival fibroblast cell-line HGF-1. In agreement with FTIR and Raman results, the XPS technique indicates that Nb is present in an oxidation state assigned to $\mathrm{Nb}_{2} \mathrm{O}_{5}$. Furthermore, the coatings produced by PVD technique are less toxic and induces less inflammation in gingival cells (cell-line HGF-1), suggesting the strategy of use $\mathrm{Nb}_{2} \mathrm{O}_{5}$ thin film to cover the $316 \mathrm{~L}$ SS promoted since its protection of the physiological environment to its biocompatibility improvement.

\section{Graphical Abstract}

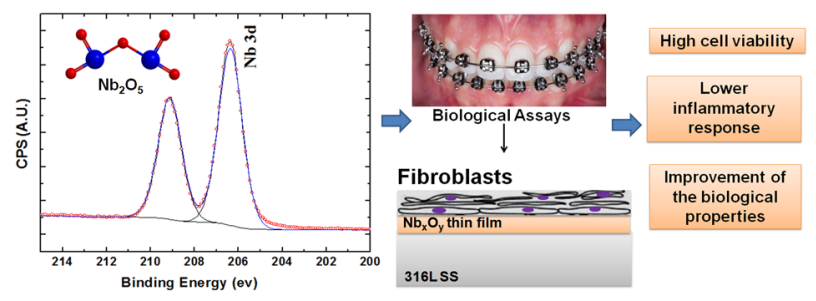

\section{Highlights}

- PVD method was shown advantageous for producing $\mathrm{Nb}_{2} \mathrm{O}_{5}$ thin film on the $316 \mathrm{~L}$ SS.

- 316L SS coated with $\mathrm{Nb}_{2} \mathrm{O}_{5}$ film to be used in biomedical devices.

- $\mathrm{Nb}_{2} \mathrm{O}_{5}$ coating improved biological response of the 316L SS.

- $\mathrm{Nb}_{2} \mathrm{O}_{5}$ thin film are less toxic and induces less inflammation in gingival cells.

$\triangle$ Jéferson Aparecido Moreto

jeferson.moreto.uftm@gmail.com

1 Institute of Exact Sciences, Naturals and Education, Federal University of Triângulo Mineiro (UFTM), Avenida Doutor Randolfo Borges Júnior, Univerdecidade, Uberaba, Minas Gerais, Brazil

2 Institute of Technological and Exact Sciences, Federal University of Triângulo Mineiro (UFTM), Avenida Doutor Randolfo Borges Júnior, Univerdecidade, Uberaba, Minas Gerais, Brazil
3 Laboratory of Immunology and Bioinformatics, Institute of Natural and Biological Sciences, Federal University of Triângulo Mineiro, Uberaba, Minas Gerais, Brazil

4 Center for Technological Sciences, UDESC, Joinville, Santa Catarina, Brazil

5 Department of Dentistry, University of Uberaba, Uberaba, Minas Gerais, Brazil 


\section{Introduction}

The development of new biomaterials has been growing in recent decades and among the requirements for its use one can cite, good resistance to the wear process, good corrosion resistance in media containing aggressive ions and biocompatibility [1]. Many methods of surface treatments can be used to obtain biomaterials with a wide variety of applications, such as anodizing [2], chemical conversion coating [3], electrodeposition [4], plasma enhanced chemical vapor deposition [5] and physical vapor deposition (PVD) [6]. Although conventional materials such as $316 \mathrm{~L}$ stainless steels (SS), titanium alloys containing hydroxyapatite doped with rare earth elements [7], titanium alloys coated with diamond-like carbon thin films [8], $\mathrm{Co}-\mathrm{Cr}$ alloys and magnesium alloys have been used for a long time as biomaterial, there are still several limitations to their use [9]. Improving the biological responses of $316 \mathrm{~L}$ SS is a long-standing and active area of biomedical research [10]. However, most studies on corrosion processes in aggressive media found in the literature do not associate them with biological effects such as cytotoxicity and biocompatibility. The biomaterials to be used in clinical practice need to fulfill many requirements once it needs to ensure the safety and effectiveness to the patient [10]. Among these requirements, we may mention the absence of cytotoxic activity, irritation and induction of the immune and inflammatory response by the biomaterial. Here, we provide new insights of $\mathrm{Nb}_{2} \mathrm{O}_{5}$-based coatings on the $316 \mathrm{~L}$ SS surface, validating its applicability potential in dentistry field to be used as brackets.

\section{Material and methods}

Specimens of 316L SS were ground with $\mathrm{SiC}$ abrasive paper from 600\# to 4000\#. Prior the deposition, the samples were immersed in neutral detergent during $1 \mathrm{~h}$, rinsed with distilled water, dried and cleaned with 70\% (v/v) alcohol. The $\mathrm{Nb}_{2} \mathrm{O}_{5}$ thin films were deposited using argon (99.99\%) and oxygen (99.99\%) at 5.0 and $0.5 \mathrm{mTorr}$ in a DCmagnetron sputtering [11]. Over a Niobium (99.99\%) 2-in. diameter target was applied $440 \mathrm{~V}$ and $140 \mathrm{~mA}$ resulting film of $300 \mathrm{~nm}$ thick.

The topography of the films was investigated by using AFM (Shimadzu SPM 9700 Microscope equipment) in tapping mode. The structural characterization of the $316 \mathrm{~L}$ SS containing $\mathrm{Nb}_{2} \mathrm{O}_{5}$ coatings was performed by FTIR technique. The spectra were collected 64 scan s $^{-1}$ using an Agilent Cary 640 spectrometer in the range of $4000-500 \mathrm{~cm}^{-1}$. An IRRAS (Infrared reflection-absorption spectroscopy) apparatus from Pike Veemax incidence at $70^{\circ}$ was used. Raman spectroscopy was performed with a
Horiba LabRAM HR Evolution instrument equipped with a confocal microscope. Spectra were collected using a $532 \mathrm{~nm} \mathrm{Ar}^{+}$laser source, $50 \mathrm{~mW}$ power, $100 \times$ objective in the range $80-4000 \mathrm{~cm}^{-1}$. The thin film was also characterized by X-ray Photoelectron Spectroscopy (XPS), using a K-Alpha Thermo Scientific spectrometer (X-ray Al$\mathrm{K} \alpha, h \nu=1486.6 \mathrm{eV}$ ), at a pressure below $10^{-7} \mathrm{mBar}$. Pass energy applied to obtain the spectra was $200 \mathrm{eV}$ for survey and $50 \mathrm{eV}$ for high-resolution scans. The spectra deconvolution was performed using the Voigtian function, with Gaussian (70\%) and Lorentzian (30\%) combinations.

Biological assays were performed using human gingival fibroblast cell-line HGF-1. Gingival fibroblasts HGF-1 (CRL-2014, ATCC) were cultured in T-25 culture vessels (Nunc), temperature of $37^{\circ} \mathrm{C}$, in an atmosphere of $5 \%$ $\mathrm{CO}_{2}$, with Dulbecco's Modified Eagle's Medium (DMEM) enriched with $10 \%$ FBS (Sigma-Aldrich, USA). DMEM medium was renewal 2 to 3 times per week until HGF-1 cells reach an $80-90 \%$ confluence. After, cells were removed using $0.25 \%$ trypsin, $0.53 \mathrm{mM}$ EDTA solution and seeded at $1 \times 10^{5}$ cells $/ \mathrm{mL}$ on the uncoated and coated $316 \mathrm{~L} \mathrm{SS}$ with $\mathrm{Nb}_{2} \mathrm{O}_{5}$ thin film. After $24 \mathrm{~h}$ of incubation at $37{ }^{\circ} \mathrm{C}, 5 \% \mathrm{CO}_{2}$, cells were mechanically removed and evaluated for viability by flow cytometry using Annexin-V plus 7-ADD staining, performed as manufacturer's instructions (BD Biosciences, USA). Cell supernatants were used for quantification of TNF- $\alpha$, IL-10, IL-17, IL-6, IFN- $\gamma$, and IL- 4 cytokines by immunoenzymatic assayELISA, performed as manufacturer's instructions (BD Biosciences, USA).

\section{Results and discussion}

The topography of 316L SS coated and uncoated obtained by AFM are displayed at Fig. 1 and presents 2D and 3D images of the specimens studied here. The second-phase particles from the steel making process, which was marked with red circles are presented in Fig. 1A. The nucleation process in the vapor phase promoted the formation of a thin film that accompanies the risks arising from the sanding process (see Fig. 1B). The root means square surface roughness values obtained were 2.94 and $2.40 \mathrm{~nm}$ for the coated and uncoated $316 \mathrm{~L}$ SS, respectively.

FTIR spectra of the $\mathrm{Nb}_{2} \mathrm{O}_{5}$ thin film in range of $1400-600 \mathrm{~cm}^{-1}$ is presented in Fig. 2A. The spectrum resulted in an intense band between 1100 and $700 \mathrm{~cm}^{-1}$. The deconvolution of this large band resulted in two other bands centered at $\sim 940$ and $\sim 844 \mathrm{~cm}^{-1}$ attributed to $\mathrm{Nb}=\mathrm{O}$ and $\mathrm{Nb}-\mathrm{O}-\mathrm{Nb}$ stretching $[12,13]$, respectively. The inset in Fig. 2A displays the whole IR spectra of $\mathrm{Nb}_{2} \mathrm{O}_{5}$ film herein studied indicating no additional bands related to the niobium oxide film. The major Raman band appears 
(A)

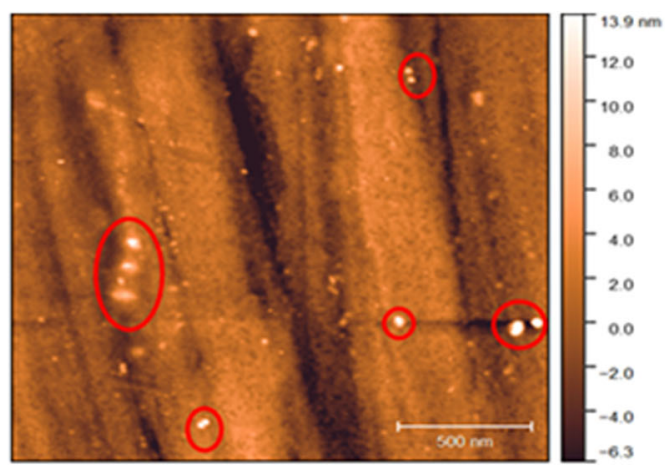

(B)

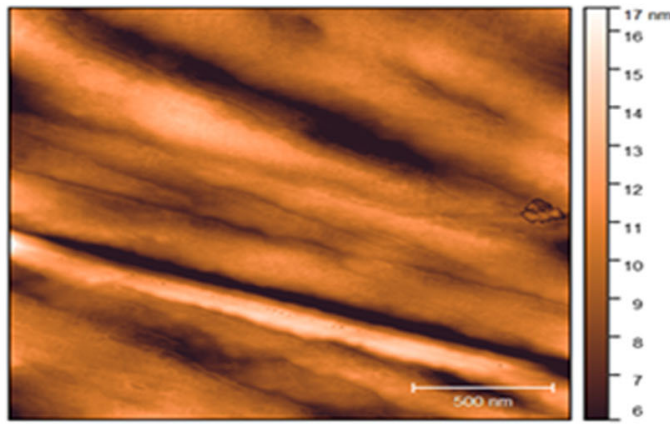

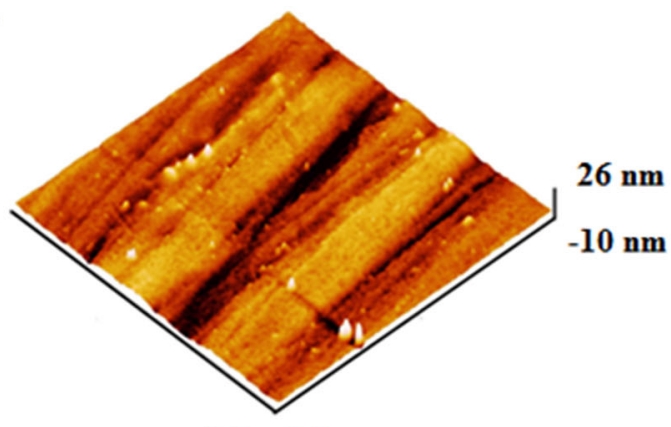

$2.0 \times 2.0 \mu \mathrm{m}$

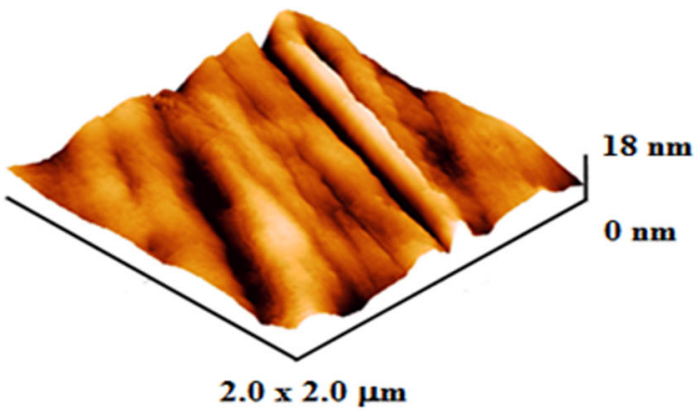

Fig. $12 \mathrm{D}$ and 3D images of $\mathbf{A} 316 \mathrm{~L}$ SS substrate, scale $2.0 \times 2.0 \mu \mathrm{m}$ and $\mathbf{B} 316 \mathrm{~L}$ SS containing the $\mathrm{Nb}_{2} \mathrm{O}_{5}$ thin film, scale $3.0 \times 3.0 \mu \mathrm{m}$

at $\sim 655 \mathrm{~cm}^{-1}$ as well as another band presenting a lower intensity around $206 \mathrm{~cm}^{-1}$ attributed to $\mathrm{Nb}_{2} \mathrm{O}_{5}[14]$ (see Fig. 2B).

Survey XPS indicates the film chemical composition as 53 at. $\%$ of oxygen, 27 at. $\%$ of carbon and 20 at.\% of niobium. The chemical states of niobium and oxygen were determined by high-resolution scans deconvolution, showed in Fig. 2C, D. Nb $3 d$ deconvolution shows doublets for $\mathrm{Nb} 3 d_{5 / 2}$ and $\mathrm{Nb} 3 d_{3 / 2}$, at $206.4 \mathrm{eV}$ and $209.1 \mathrm{eV}$, respectively. In agreement with FTIR and Raman results, it indicates that $\mathrm{Nb}$ is present in an oxidation state assigned to $\mathrm{Nb}_{2} \mathrm{O}_{5}[15,16]$. Also, $\mathrm{O} 1 \mathrm{~s}$ deconvolution presents a major contribution (83 at.\%) of the peak at $529.5 \mathrm{eV}$, assigned to $\mathrm{Nb}_{2} \mathrm{O}_{5}$ [16]. The other peak, at $531.1 \mathrm{eV}$, is related to $-\mathrm{OH}$ groups and/or oxidized carbon species [17]. These results confirm the thin film formation preferentially composed by niobium in $\mathrm{Nb}_{2} \mathrm{O}_{5}$ oxidation state.

The biological results presented that the 316L SS containing the $\mathrm{Nb}_{2} \mathrm{O}_{5}$ thin film induces significantly less cell death, as demonstrated by total apoptosis (Annexin- $\mathrm{V}+$ cells, $p=0.02$ ), early apoptosis (Annexin-V + 7-ADDcells, $p=0.02$ ) and late apoptosis (Annexin-V + 7-ADD + cells, $p=0.04$ ) evaluation. Figure 3 displays the HGF-1 cellline cultured on the coated and uncoated 316L SS substrates. As can be seen, the total (A), early (B) and late apoptosis (C) are demonstrated. The results showed the $\mathrm{Nb}_{2} \mathrm{O}_{5}$ thin film improved the biocompatibility of the 316L SS substrate.
Probably, the increase of the biocompatibility may be related to the surface properties, particularly the surface energy and surface wettability as related by Hao and Lawrence [18]. Niobium coatings are biocompatible to fibroblast cells that assumed the elongated fibroblastic appearance typical of osteoblast-like cells. The results obtained in the present work are in accordance to Eisenbarth et al. [19], which attributes the increase viability, proliferation, mitochondrial and osteogenic activity of titanium implants to the niobium-based films on the substrate surfaces.

In addition to improving cell compatibility by reducing cell toxicity of tested surfaces, it is desirable that biomaterials do not induce harmful inflammation after cell contact. In this context, the $316 \mathrm{~L}$ SS containing the $\mathrm{Nb}_{2} \mathrm{O}_{5}$ thin film induces significantly less TNF- $\alpha$ production, a huge pro-inflammatory cytokine involved in a diversity of inflammatory and autoimmune diseases $(p=$ 0.02 ), and similar levels of IL-10, a classical antiinflammatory cytokine (see Fig. 4A, B). Besides, the 316L SS containing $\mathrm{Nb}_{2} \mathrm{O}_{5}$ film induced less production of IL-17 ( $p=0.001)$, other cytokine deeply involved in inducing and mediating pro-inflammatory responses (Fig. 4C). We also observed a similar production of IL-6, besides a trend to lower levels in $316 \mathrm{~L}$ SS coated with $\mathrm{Nb}_{2} \mathrm{O}_{5}(p=0.06)$. Like TNF- $\alpha$ and IL-17, IFN-y, and IL-4 are important inflammatory cytokines, however, these molecules were not changed in the culture with all the films tested (Fig. 4D-F). 

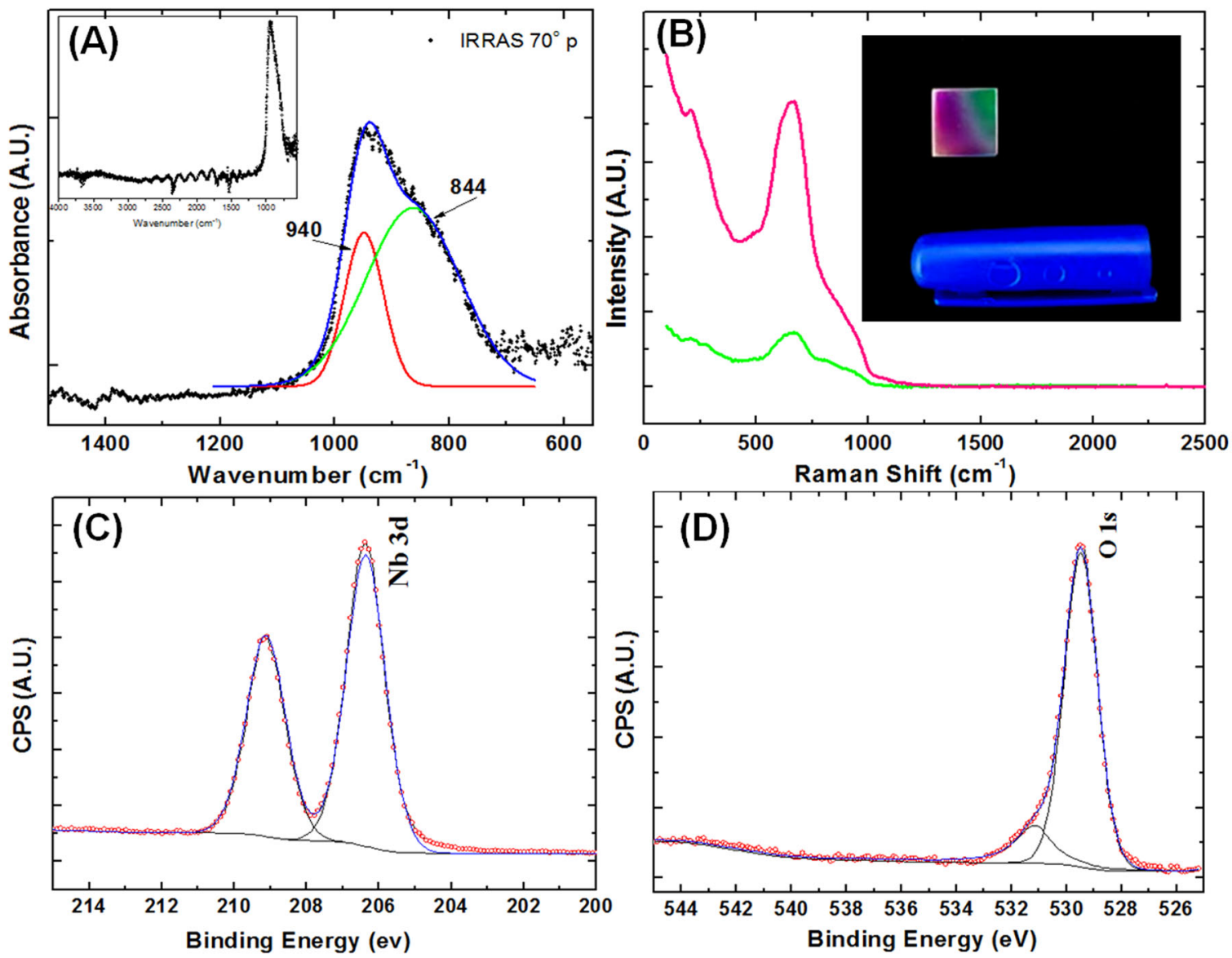

Fig. 2 A FTIR-IRRAS spectrum obtained at $70^{\circ}$ p-polarized for $\mathrm{Nb}_{2} \mathrm{O}_{5}$ thin film showing the bands centered at 844 and $940 \mathrm{~cm}^{-1}$ (inset displays the FTIR spectra in the range 4000 to $500 \mathrm{~cm}^{-1}$ ). B Raman spectra

for the 316L SS containing $\mathrm{Nb}_{2} \mathrm{O}_{5}$ film (inset displays the different regions of the film and its spectra). $\mathbf{C ~ N b} 3 d$ levels and D O $1 s$ XPS deconvolution spectra

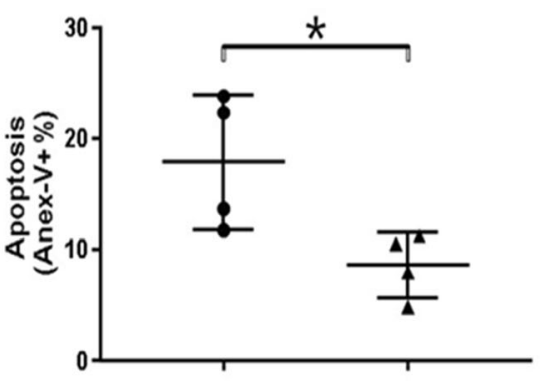

(A)

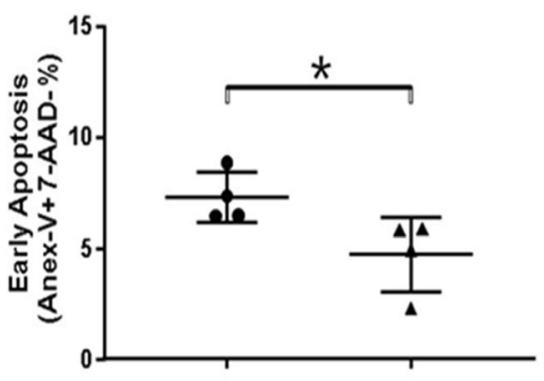

(B)

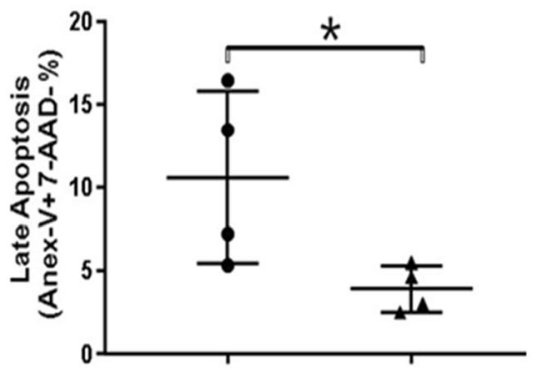

(C)

Fig. 3 HGF-1 cell-line cultured on the coated and uncoated 316L SS substrates, A total, B early, and $\mathbf{C}$ late apoptosis. Points represent each

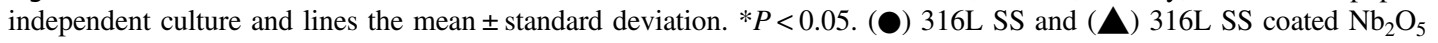

TNF- $\alpha$ is directly involved in inflammation maintenance and activation of osteoblasts, inducing bone desorption, and films that act inducing lower concentrations are more biocompatible in a long term [20], such as demonstrated by lower levels of TNF- $\alpha$ production by murine macrophage cells cultured with niobium-covered surfaces [21]. In a similar way, IL-17 is a huge pro-inflammatory cytokine associated with chronic inflammation [22], osteoclastogenesis [22] and that can amplify inflammatory responses by inducing TNF- $\alpha$ secretion by macrophages [23]. 


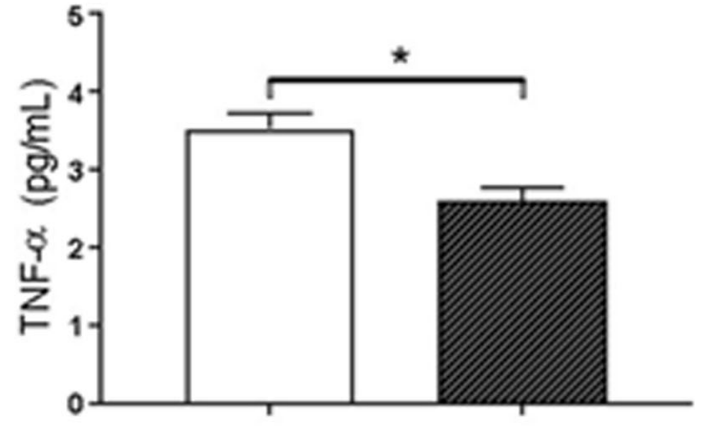

(A)

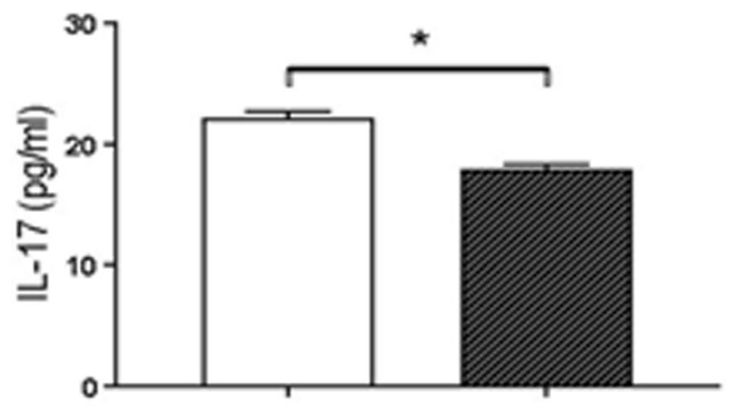

(C)

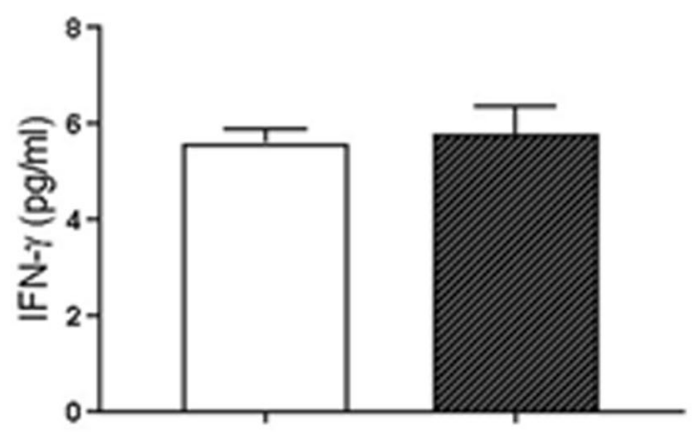

(E)

Fig. 4 Effect of 316L SS coated and uncoated in cytokine production of HGF-1. The cells were cultured for $24 \mathrm{~h}$ on both specimens. After $24 \mathrm{~h}$ of culture supernatant was collected and TNF- $\alpha$ (A), IL-10 (B), IL-17 (C), IL-6 (D), IFN- $\gamma$ (E) and IL-4 (F) were analyzed by

\section{Conclusion}

The PVD method was shown advantageous for producing $\mathrm{Nb}_{2} \mathrm{O}_{5}$ thin film on the $316 \mathrm{~L}$ SS surface. The coatings produced are less toxic and induces less inflammation than $316 \mathrm{~L}$ SS in gingival cells (cell-line HGF-1) with high prospects to be used in the dentistry field as orthodontic brackets. The biological results suggest that the strategy of use $\mathrm{Nb}_{2} \mathrm{O}_{5}$ thin film to cover the $316 \mathrm{~L}$ SS promoted since its protection of the physiological environment to its biocompatibility improvement. Furthermore, this study is the starting point for

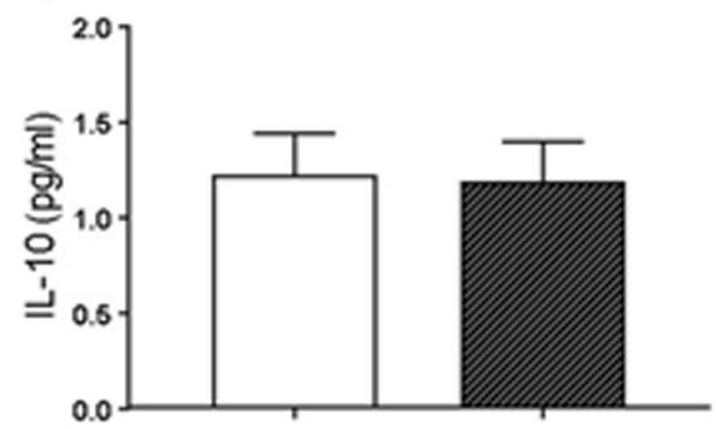

(B)

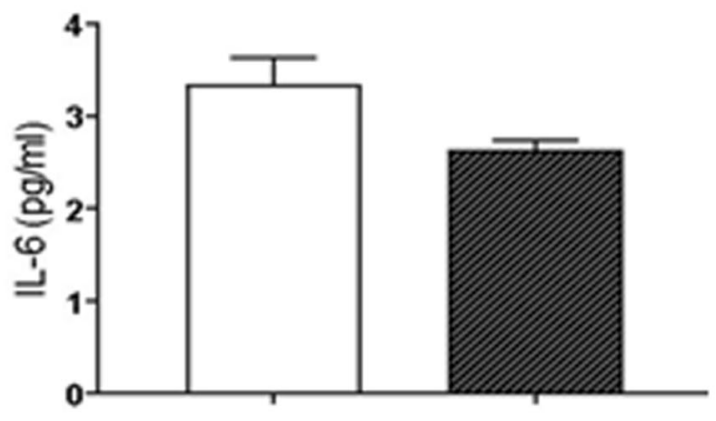

(D)

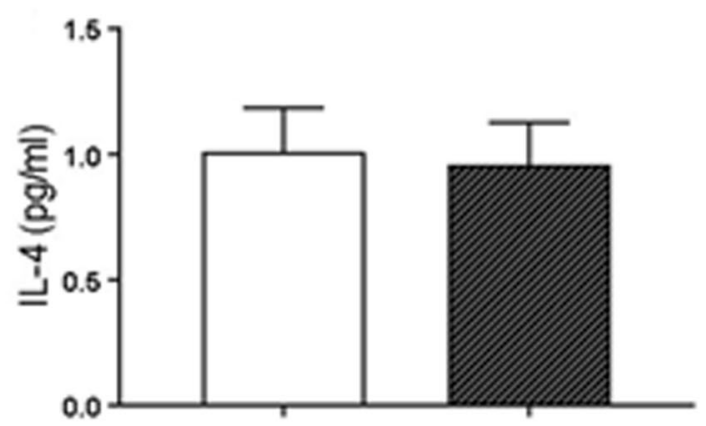

(F)

cytometric bead array (CBA). Bars represent the mean \pm standard deviation of cytokine production from quadruplicate samples. $* P<$ 0.05. (口) 316 L SS and $(\square) 316 \mathrm{~L} \mathrm{SS}$ coated $\mathrm{Nb}_{2} \mathrm{O}_{5}$

the development of robust studies in biomedical area by using $\mathrm{Nb}_{2} \mathrm{O}_{5}$ thin film as a protective barrier against corrosion process and enhanced biological responses.

Acknowledgements JAM would like to thank the National Council of Technological and Scientific Development (CNPq) grant 303659/ 2019-0 and FAPEMIG grant APQ-02276-18. RVG also thank Companhia Brasileira de Metalurgia e Mineração (CBMM) and CNPq grant 440726/2020-4. All authors would like to thank Horiba LabRAM HR Evolution Raman microscope at the Institute of Physics (INFIS) supported by the grant "Pró-Equipamentos" from the Brazilian Agency CAPES. 


\section{Compliance with ethical standards}

Conflict of interest The authors declare no competing interests.

Publisher's note Springer Nature remains neutral with regard to jurisdictional claims in published maps and institutional affiliations.

Open Access This article is licensed under a Creative Commons Attribution 4.0 International License, which permits use, sharing, adaptation, distribution and reproduction in any medium or format, as long as you give appropriate credit to the original author(s) and the source, provide a link to the Creative Commons license, and indicate if changes were made. The images or other third party material in this article are included in the article's Creative Commons license, unless indicated otherwise in a credit line to the material. If material is not included in the article's Creative Commons license and your intended use is not permitted by statutory regulation or exceeds the permitted use, you will need to obtain permission directly from the copyright holder. To view a copy of this license, visit http://creativecommons. org/licenses/by/4.0/

\section{References}

1. Rajan ST, Bendavid A, Subramanian B. Cytocompatibility assessment of $\mathrm{Ti}-\mathrm{Nb}-\mathrm{Zr}-\mathrm{Si}$ thin film metallic glasses with enhanced osteoblast differentiation for biomedical applications. Coll Surf B: Biointerfaces. 2018. https://doi.org/10.1016/j. colsurfb.2018.09.041.

2. Qianyu Z, Li X. High rate capability of Nd-doped $\mathrm{Li}_{4} \mathrm{Ti}_{5} \mathrm{O}_{12}$ as an effective anode material for lithium-ion battery. Int J Electrochem. Sci. 2013;8:7816-7824.

3. Caiwen O, Wei L, Zailei Z, Ping H, Pengfei Y, Biao Y, Minsheng C. Effect of $\mathrm{Ca}$ and $\mathrm{P}$ ion concentrations on the structural and corrosion properties of biomimetic Ca-P coatings on ZK60 magnesium alloy. Int J Electrochem Sci. 2013. https://doi.org/10.1016/j. msec.2016.11.132

4. Zhong C, Liu F, Wu YT, Le JJ, Liu L, He MF, Zhu JC, Hu WB. Protective diffusion coatings on magnesium alloys: a review of recent developments. J Alloy Compd. 2012. https://doi.org/10. 1016/j.jallcom.2011.12.124

5. Aisenberg S, Chabot R. Ion-beam deposition of thin films of diamond-like carbon. J Appl Phys J Appl Phys. 1971. https://doi. org/10.1063/1.1660654

6. Rausch M, Golizadeh M, Kreiml P, Cordill MJ, Winkler J, Mitterer C. Sputter deposition of NiW films from a rotatable target. Appl Surf Sci. 2020. https://doi.org/10.1016/j.apsusc.2020.145616.

7. Deng Z, Wang L, Zhang D, Liu J, Liu C, Ma J. Med Sci Monit. 2014; https://doi.org/10.12659/MSM.889894.

8. Kobayashi S, Ohgoe Y, Ozeki K, Sato K, Sumiya T, Hirakuri KK, Aoki H. Diam Relat Mater. 2005. https://doi.org/10.1016/j.dia mond.2004.11.036.

9. Eliaz N. Corrosion of metallic biomaterials: a review. Materials. 2019. https://doi.org/10.3390/ma12030407.
10. Eurídice WA, Bueno Leite N, Gelamo RV, Buranello PAA, da Silva VM, Oliveira CJF, et al. a-C:H films produced by PECVD technique onto substrate of Ti6Al4V alloy: chemical and biological responses. Appl Surf Sci. 2020; https://doi.org/10.1016/j. apsusc.2019.144084.

11. Machuno LGB, Lima AB, Buso RR, Abdanur RMF, Rangel EC, Gelamo RV. Desenvolvimento e avaliação de uma fonte DC de alta tensão para utilização em sistema de deposição de filmes finos por pulverização catódica. Rev Matér. 2016. https://doi.org/10. 1590/S1517-707620160002.0046.

12. Orel B, Maček M, Grdadolnik J, Meden A. In situ UV-Vis and ex situ IR spectroelectrochemical investigations of amorphous and crystalline electrochromic $\mathrm{Nb} 2 \mathrm{O} 5$ films in charged/discharged states. J Solid State Electrochem. 1998. https://doi.org/10.1007/ s100080050092.

13. Burcham LJ, Datka J, Wachs IE. In situ vibrational spectroscopy studies of supported niobium oxide catalysts, J. Phys. Chem. B. 1999; https://doi.org/10.1021/jp990289a.

14. Jehng JM, Wachs IE. Structural chemistry and Raman spectra of niobium oxides. Chem Mater. 1991. https://doi.org/10.1021/ cm00013a025.

15. Pillis MF, de Oliveira MCL, Antunes RA. Surface chemistry and the corrosion behavior of magnetron sputtered niobium oxide films in sulfuric acid solution. Appl Surf Sci. 2018. https://doi.org/ 10.1016/j.apsusc.2018.08.123.

16. Yang Z, Lu X, Tan W, Zhao J, Yang D, Yang Y, He Y, Zhou K. XPS studies of nitrogen doping niobium used for accelerator applications. Appl Surf Sci. 2018. https://doi.org/10.1016/j. apsusc.2017.12.214.

17. Bekermann D, Barreca D, Gasparotto A, Becker HW, Fischer RA, Devi A. Investigation of niobium nitride and oxy-nitride films grown by MOCVD. Surf Coat Technol. 2009. https://doi.org/10. 1016/j.surfcoat.2009.07.029.

18. Hao L, Lawrence J. Effects of $\mathrm{CO}_{2}$ laser irradiation on the wettability and human skin fibroblast cell response of magnesia partially stabilised zirconia. Mater Sci Eng C. 2003. https://doi.org/ 10.1016/S0928-4931(03)00056-0.

19. Eisenbarth E, Velten D, Müller M, Thull R, Breme J. Biocompatibility of beta-stabilizing elements of titanium alloys. Biomaterials. 2004; https://doi.org/10.1016/j.biomaterials.2004. 01.021 .

20. Lin T, Tamaki Y, Pajarinen J, Rogan H, Woo D, Yao Z, Goodman S. Chronic inflammation in biomaterial-induced periprosthetic osteolysis: NF-кB as a therapeutic target. Acta Biomater. 2013. https://doi. org/10.1016/j.actbio.2013.09.034.

21. Vandrovcova M, Jirka I, Novotna K, Lisa V, Frank O, Kolska Z, Stary V, Bacakova L. Interaction of human osteoblast-like Saos-2 and MG-63 cells with thermally oxidized surfaces of a titaniumniobium alloy. PLoS ONE. 2014; https://doi.org/10.1371/journal. pone. 0100475 .

22. Kuwabara T, Ishikawa F, Kondo M, Kakiuchi T. The Role of IL17 and related cytokines in inflammatory autoimmune diseases. Mediators Inflamm. 2017; https://doi.org/10.1155/2017/3908061

23. Miossec P, Kolls JK Targeting IL-17 and TH17 cells in chronic inflammation. Nat Rev Drug Discov. 2012; https://doi.org/10. 1038/nrd3794. 